\title{
Land Capability Evaluation in the Caldera of Mount Batur-Bali
}

\author{
Dewa Made Atmaja ${ }^{1}$, I Gede Budiarta $^{1}$ \\ made.atmaja@undiksha.ac.id, gede.budiarta@undiksha.ac.id \\ ${ }^{1}$ Universitas Pendidikan Ganesha, Indonesia
}

\begin{abstract}
The purpose of this study was to map and evaluate the distribution of land capability of the Mount Batur Caldera by applying land evaluation; The main objective of this research is to increase food security and reduce the rate of land degradation in the Mount Batur Caldera. The method used is grouping land into units and assessing its characteristics and quality. The guidelines referred to are Minister of Environment Regulation No. 17 of 2009. The map of land units is made with basic data in the form of Landsat 8 images and a Digital Earth Map of Indonesia by applying the working principles of Remote Sensing and Geographic Information Systems (GIS). The software for image processing is ER Mapper, while for mapping and database creation using ArcGIS. Determination of area function criteria refers to the guidelines of the Decree of the Minister of Agriculture Number 837/Kpts/Um/11/1980 and Number: $683 / \mathrm{Kpts} / \mathrm{Um} / 8 / 1981$. The results obtained from this study are the land capacity in the research area ranging from class IV to class VIII which is spread over each land unit according to the land capability map produced in this study. Land capability consists of eight classes. Class I is the class most cultivated for agriculture and non-agriculture. In the research area, land that can be cultivated is class I to IV. Other classes cannot be used.
\end{abstract}

Keywords: evaluation; land capability; Landsat 8

\section{Introduction}

The phenomena studied and become the objectives in this study are related to land capability classification based on existing geospatial phenomena on the caldera of Mount Batur-Bali. Batur Caldera is a geographical area located in Kintamani District, Bangli Regency, Bali Province. Astronomically, Batur Caldera is located between $8^{\circ} 11^{\prime} 15^{\prime \prime}-8^{\circ} 17^{\prime}$ 35" South Latitude and $115^{\circ} 19^{\prime} 10^{\prime \prime}-115^{\circ} 17^{\prime} 35^{\prime \prime}$ East Longitude. Viewed based on administrative boundaries, the Batur Caldera area consists of 14 villages (Mosaic of the Indonesian Earth Map Sheet Batur (1707-623), Kedisan (1707-624), Kintamani (1707-641), and Sambirenteng (1707-642). These villages include Sukawana, Kintamani, North Batur, South Batur, Central Batur, Kedisan, Buahan, Abangsongan, Trunyan, Songan A, Songan B, Suter, Pinggan and Belandingan village. According to Hadiwidjojo, et al. (1998), the geological conditions of the Batur Caldera are Qhvb (rocks of Batur Volcano, especially agglomerates, lava and tuff, a little lahar and ignimbrites), Qvbb (volcanic rocks of the ancient Buyan-Beratan group, volcanic breccias and lava, local tuff). The morphology of the Batur 
Caldera or Molengraaf Caldera, illustrated by Bemmelen (1970), is a large caldera with a diameter of $\pm 10 \mathrm{~km}$ northwest-southeast. Batur Caldera is enclosed on each side and is an example of the largest and most beautiful caldera in the world. Based on the analysis of the Bali Hydrological Map with a scale of 1: 250,000 and the Bali Review Soil Map in 1970, the groundwater content in the Batur Caldera is large (10 liters/second) in the southern and eastern outskirts of the lake, the water content is very low ( 0.1 liters/second) on the outskirts of the caldera, and very few ( $<0.1$ liters/second) in the cone area of the Batur volcano. The type of soil found in the caldera area is Re.g-ViU.Vk (Grey Regosol) with intermediate volcanic ash as the parent material with physiography of caldera valley and volcanic cones. In addition having natural beauty and attraction for tourists, Batur Caldera also has agricultural potential which can be seen from the existence of agricultural activities in the area.

The availability of a spatial database on the potential of natural resources is very necessary for future land use planning. It is also important to know the potential land capability contained in the Mount Batur caldera. Information on land capability will provide an overview of land management that must be carried out to obtain optimal results to improve the welfare of farmers. There are at least two reasons why this research feels important to do; 1) there is no information on land capability class in the Batur Caldera ; 2) The Batur Caldera has various physiographic characteristics and stores the potential of natural resources, so that the design of spatial databases and mapping of areas, especially those related to the distribution of natural resources, is very necessary.

\section{Methods \\ Research Design}

This study focuses on the analysis of the carrying capacity of the land to produce thematic geospatial information related to the land capability and the status of the environmental carrying capacity. The design used in this study is a descriptive design study applies a spatial approach as well as an environmental approach in assessing the problems that exist in the research area. The spatial approach emphasizes the diversity of the earth's surface by examining each of its spatial aspects. The spatial aspects of the earth include the factors of location, natural conditions, and sociocultural conditions of the community. In examining these aspects, the spatial approach pays close attention to the factors of location, distribution, interrelation, and their interactions.

\section{1) Pre-Field Work}

The preliminary study is focused on identifying land units/units in the research area. According to Sitorus (1985), a land unit is a plot of land that has similarities in terms of soil type, slope, and land use. In this preliminary study, general observations were made regarding the condition of soil type, slope, and land use, as well as image interpretation.

\section{2) Field Work Stage}

The activities carried out at the fieldwork stage are essentially direct measurements of land characteristics, as well as taking research samples on each land unit for analysis in the laboratory (Soil Laboratory, Faculty of Agriculture, Udayana University), in order to determine the quality and characteristics of the land. 
3) Post- Field Work

Conduct an analysis of the various variables and draw a conclusion from the research conducted.

\section{Research sites}

This research was conducted in the caldera of Mount Batur, Bangli Regency, Bali Province.

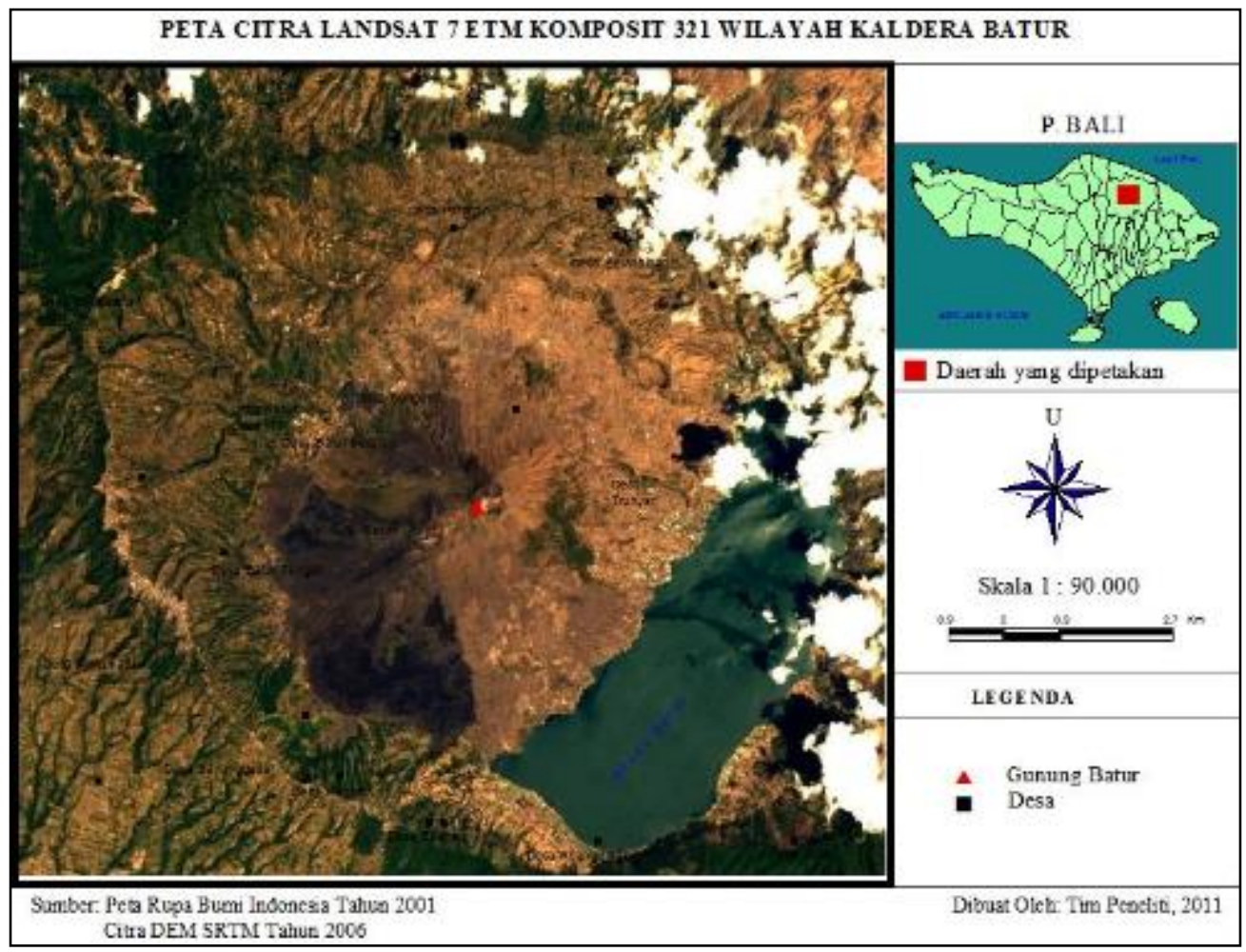

Figure 1 Research Location Map

\section{Research Subjects and Objects}

The research subject is land potential. The object of research is the land unit. 


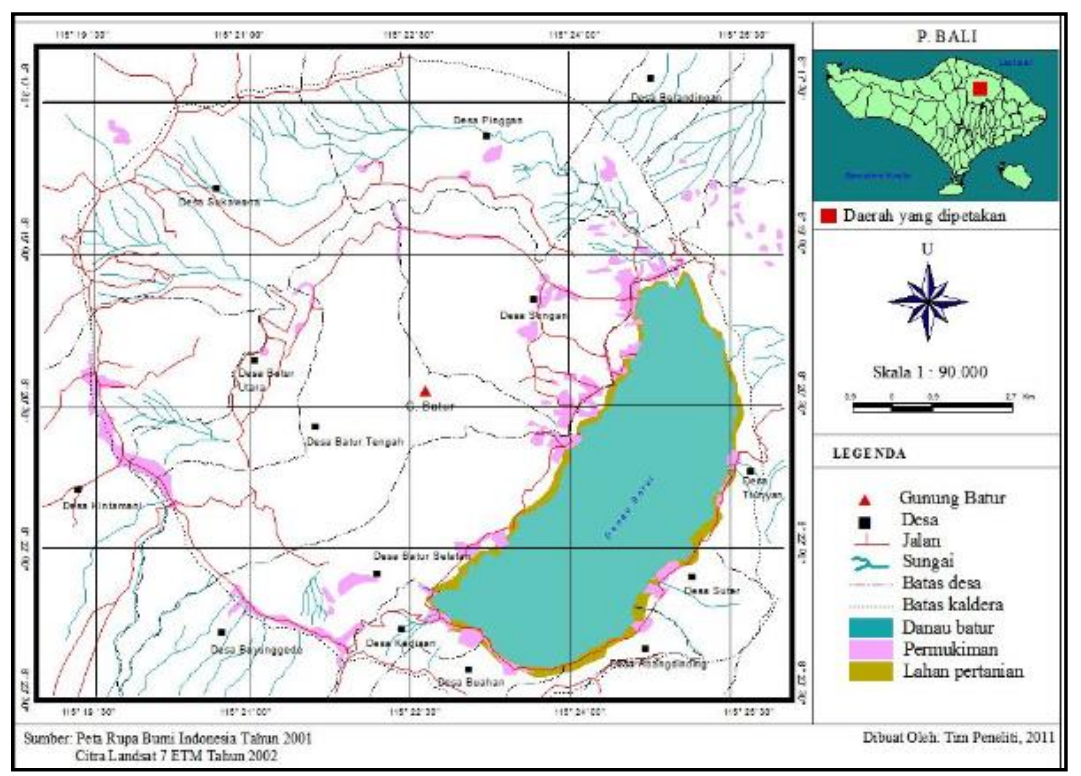

Figure 2 Research Administration Map

\section{Data Analysis}

The data analysis technique used in this research is descriptive-qualitative.

1) Determination of Land Capability Class

The land capability class classification uses the following criteria.

Table 1. Land Capability Class Criteria

\begin{tabular}{|c|c|c|c|c|c|c|c|c|}
\hline Limiting Factor & Land & apabilit & Class & & & & & \\
\hline 1. Soil texture $(\mathrm{t})$ & $\mathrm{I}$ & II & III & IV & $\mathrm{V}$ & VI & VII & VIII \\
\hline a. upper layer & $\begin{array}{l}\mathrm{t}_{2} / \mathrm{t}_{3} \\
\mathrm{t}_{2} / \mathrm{t}_{3}\end{array}$ & $\begin{array}{l}\mathrm{t}_{1} / \mathrm{t}_{4} \\
\mathrm{t}_{1} / \mathrm{t}_{4}\end{array}$ & $\begin{array}{l}\mathrm{t}_{1} / \mathrm{t}_{4} \\
\mathrm{t}_{1} / \mathrm{t}_{4}\end{array}$ & $\begin{array}{l}(*) \\
(*)\end{array}$ & $\begin{array}{l}(*) \\
(*)\end{array}$ & $\begin{array}{l}(*) \\
(*)\end{array}$ & $\begin{array}{l}(*) \\
(*)\end{array}$ & $\begin{array}{l}t_{5} \\
t_{5}\end{array}$ \\
\hline 2. Slope $(\%)$ & Lo & $1_{1}$ & $1_{2}$ & 13 & $\left({ }^{*}\right)$ & 14 & 15 & $\mathrm{~L} 6$ \\
\hline 3 Drainage & $\mathrm{do}_{0} / \mathrm{d}_{1}$ & $\mathrm{~d}_{2}$ & $\mathrm{~d}_{3}$ & $\mathrm{~d}_{4}$ & $(* *)$ & $(*)$ & $\left({ }^{*}\right)$ & $(*)$ \\
\hline 4. Effective depth & ko & $\mathrm{ko}$ & $\mathrm{k}_{1}$ & $\mathrm{k}_{2}$ & $\left({ }^{*}\right)$ & $\mathrm{K}_{3}$ & $(*)$ & $(*)$ \\
\hline 5. Erosion & eo & $\mathrm{e}_{1}$ & $\mathrm{e}_{1}$ & $\mathrm{e}_{2}$ & $\left({ }^{*}\right)$ & $\mathrm{e}_{3}$ & $\mathrm{e}_{4}$ & $(*)$ \\
\hline 6. Gravel & bo & bo & bo & $\mathrm{b}_{1}$ & $\mathrm{~b}_{2}$ & $\left({ }^{*}\right)$ & $(*)$ & $\mathrm{b}_{3}$ \\
\hline 7. Flood & $\mathrm{O}_{0}$ & $\mathrm{O}_{1}$ & $\mathrm{O}_{2}$ & $\mathrm{O}_{3}$ & $\mathrm{O}_{4}$ & $(*)$ & $(*)$ & $(*)$ \\
\hline
\end{tabular}

Source: Minister Of Environment Regulation Number 17 Of 2009 
The land capability class of the research area will be determined based on the intensity of each inhibiting / limiting factor.

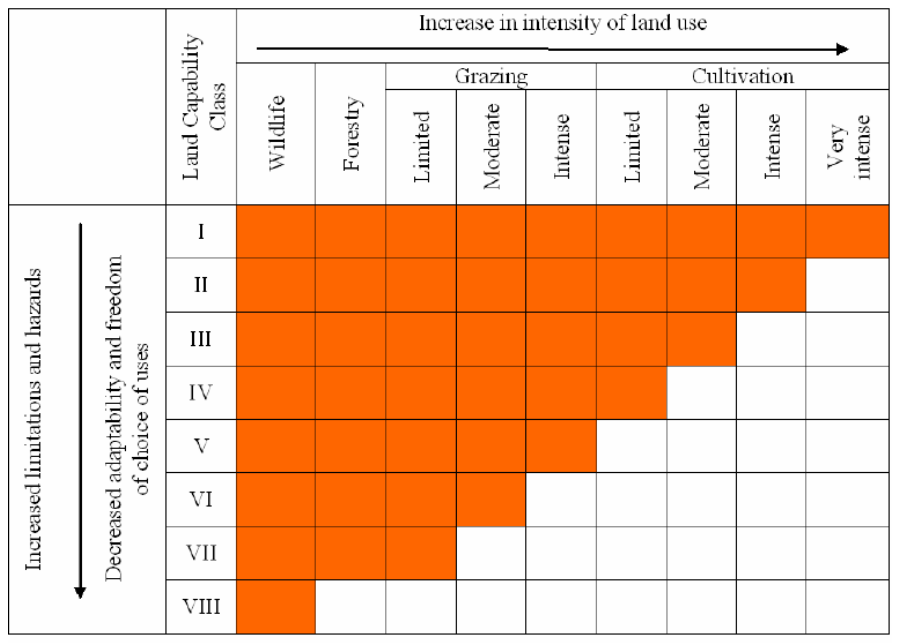

Figure 3. General Outline of Land Capability System

\section{Results and Discussion}

The results of this study are described in the following table.

Table 2. Land Capability in the Research Area

\begin{tabular}{|c|c|c|c|c|c|c|c|c|c|c|}
\hline No & Land Unit & Limiting & actor & & & & & & & Land \\
\hline (1) & (2) & $\begin{array}{l}\text { Upper } \\
\text { texture } \\
(3)\end{array}$ & $\begin{array}{l}\text { Lower } \\
\text { texture } \\
(4)\end{array}$ & $\begin{array}{l}\text { Slope } \\
(5)\end{array}$ & $\begin{array}{l}\text { Drainage } \\
(6)\end{array}$ & $\begin{array}{l}\text { Effective } \\
\text { depth } \\
(7)\end{array}$ & $\begin{array}{l}\text { Erosion } \\
\text { (8) }\end{array}$ & $\begin{array}{l}\text { Gravel } \\
\text { (9) }\end{array}$ & $\begin{array}{l}\text { Flood } \\
\text { (10) }\end{array}$ & $\begin{array}{l}\text { capabilit } \\
\text { y class } \\
(11)\end{array}$ \\
\hline 1 & $\begin{array}{l}\text { 4/V6, C, Reg. } \\
\text { Kel., P }\end{array}$ & $\mathrm{t}_{4}$ & $t_{5}$ & $1_{2}$ & $\mathrm{~d}_{2}$ & $\mathrm{k}_{2}$ & $\mathrm{e}_{2}$ & $b_{1}$ & $\mathrm{O}_{0}$ & IV \\
\hline 2 & $\begin{array}{l}5 / \mathrm{V}_{7}, \mathrm{~B}, \mathrm{Reg} . \\
\text { Cok., Lk }\end{array}$ & $\mathrm{t}_{4}$ & $t_{5}$ & $l_{1}$ & $\mathrm{~d}_{2}$ & $\mathrm{k}_{3}$ & $e_{1}$ & $b_{1}$ & $\mathrm{O}_{0}$ & V \\
\hline 3 & $\begin{array}{l}\text { 6/V7, B, Reg. } \\
\text { Kel., Lk }\end{array}$ & $\mathrm{t}_{5}$ & $\mathrm{t}_{5}$ & $l_{1}$ & $\mathrm{~d}_{0} / \mathrm{d}_{1}$ & $\mathrm{k}_{3}$ & $\mathrm{e}_{1}$ & $b_{2}$ & $\mathrm{o} 0$ & VI \\
\hline 4 & $\begin{array}{l}\text { 7/V8, } \\
\text { Reg. } \\
\text { Lk }\end{array}$ & $\mathrm{t}_{5}$ & $\mathrm{t}_{5}$ & 16 & $\mathrm{~d}_{0} / \mathrm{d}_{1}$ & $\mathrm{k}_{2}$ & $\mathrm{e}_{1}$ & $\mathrm{~b}_{1}$ & $\mathrm{O} 0$ & VII \\
\hline 5 & $\begin{array}{l}{ }^{8} / \mathrm{V}_{8}, \mathrm{~B}, \text { Reg. } \\
\text { Cok., Lk }\end{array}$ & $\mathrm{t}_{2}$ & $t_{5}$ & $\mathrm{~L}_{6}$ & $\mathrm{~d}_{0} / \mathrm{d}_{1}$ & $\mathrm{k}_{2}$ & $\mathrm{e}_{1}$ & $\mathrm{~b}_{3}$ & $\mathrm{O}_{0}$ & VIII \\
\hline
\end{tabular}


Table 2 shows that there is considerable potential that can be developed. This potential should be managed by the community. They must take advantage of the potential of the village in order to increase their income.

The advice given for land use is dependent on the potential of the village land. It is recommended to maximize land class I to class IV land because the land is fertile. Other lands are less suitable for agriculture because of the many limiting factors.

Table 3. Land Capability And Its Use In The Caldera of Mount Batur

\begin{tabular}{|c|c|c|c|}
\hline $\begin{array}{l}\text { Land } \\
\text { Class }\end{array}$ & Land Criteria & Land Use & Spread Area \\
\hline (1) & (2) & (3) & (4) \\
\hline IV & $\begin{array}{l}\text { The ability of the land is moderate, has a slightly wet } \\
\text { barrier, thereby reducing the choice of land use, } \\
\text { requires special conservation measures, suitable for } \\
\text { certain food crops with moderate intensification. }\end{array}$ & Moor & Caldera valley \\
\hline V & $\begin{array}{l}\text { Land capability is rather poor, moderately damaged, } \\
\text { thin soil solum, wavy relief, moderately eroded, and } \\
\text { a lot of rocky. The land is not suitable for annual } \\
\text { crops, it is better for permanent vegetation or } \\
\text { forestry. }\end{array}$ & $\begin{array}{l}\text { Mixed } \\
\text { garden }\end{array}$ & $\begin{array}{l}\text { Volcanic slopes and } \\
\text { caldera valleys }\end{array}$ \\
\hline VI & $\begin{array}{l}\text { Poor land capability, thin soil solum, wavy to } \\
\text { slightly hilly topography, better for permanent } \\
\text { vegetation or forested. }\end{array}$ & $\begin{array}{l}\text { Bush and } \\
\text { vacant } \\
\text { land }\end{array}$ & $\begin{array}{l}\text { Volcanic slopes and } \\
\text { caldera valleys }\end{array}$ \\
\hline VII & $\begin{array}{l}\text { Very poor land capability, heavy damage, difficult } \\
\text { to repair, rough relief, heavy erosion, better forested. }\end{array}$ & Bare land & Slope of the volcano \\
\hline VIII & $\begin{array}{l}\text { The land capability is very poor, the damage is very } \\
\text { heavy, the relief is rough, the erosion is heavy, it } \\
\text { should be forested and left natural. }\end{array}$ & Bare land & Slope of volcano \\
\hline
\end{tabular}




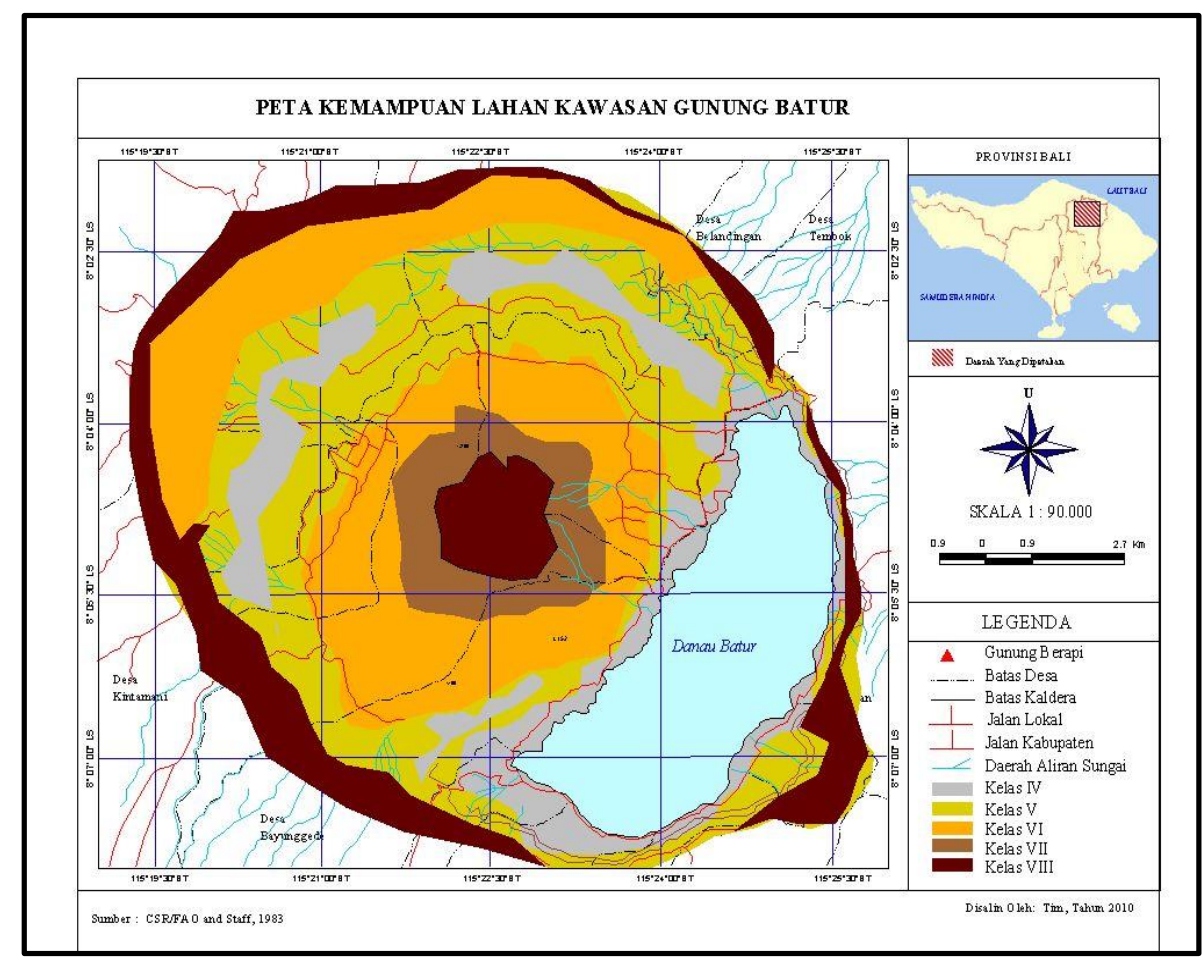

Figure 4. Land Ability Map of Batur Caldera

\section{References}

[1] Arsyad, Sitanala.: Soil and Water Conservation. Bogor: Bogor Agricultural University. (1989)

[2] Arsyad, Sitanala.: Soil and Water Conservation 2nd Edition Bogor: Bogor Agricultural University Press.(2006)

[3] Attachment to the Regulation of the Director General of Land Rehabilitation and Social Forestry Number: P.04

/ V-Set / 2009. Guidelines for Monitoring and Evaluation of Watersheds. Jakarta: Director General of RLPS (2009)

[4] Bakosurtanal.: Arc / Info Geographical Information Systems. Jakarta: Implementation of BAKOSURTANAL Education and Training. (1985)

[5] Bappeda Bali Province.: Hydrological Map of Bali Province. Denpasar: Bali Provincial Development Planning Agency. (2010) 
[6] Bappeda Bali Province.: Map of Bali Province Slope Slope. Denpasar: Bali Provincial Development Planning Agency. (2010)

[7] Bappeda Bali Province.: Land Use Map of Bali Province. Denpasar: Bali Provincial Development Planning Agency. (2010)

[8] Campbell, James B.: Introduction to Remote Sensing $3^{\text {rd }}$ ed. New York: The Guilford Press. (2002)

[9] National Survey and Mapping Coordinating Board.: Digital Topographic Maps of Indonesia Sheet Kubu. Jakarta: Bakosurtanal. (2001)

[10]Regulation of the State Minister for the Environment Number 17 of 2009 concerning Guidelines for Determining the Supporting Capacity of the Environment in Spatial Planning. (2009) 